\title{
ZINĀTNES POLITIKA LATVIJĀ: PROBLĒMAS UN PERSPEKTİVAS
}

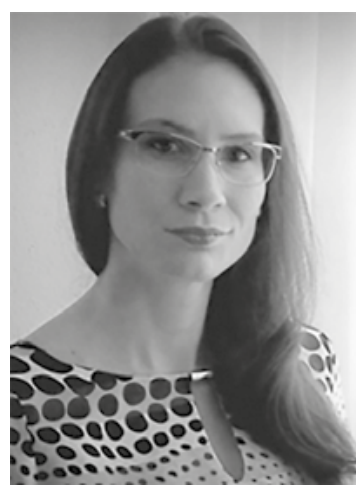

Inese Grumolte-Lerhe ir ieguvusi doktora zinātnisko grādu politikas zinātnē, kā arī maǵistra grādu ar izcilību Latvijas Universitātē. İstenojusi pētniecības projektus vairākās ārvalstu zinātniskajās institūcijās - Bāzeles Universitātē (Šveice), Berlīnes brīvajā Universitātē (Vācija), J. V. Gētes Universitātē Frankfurtē pie Mainas (Vācija), Tartu Universitātē (Igaunija) u. c. Piedalījusies valsts pētījumu programmas Nacionālā identitāte (valoda, Latvijas vēsture, kultūra un cilvēkdrošība) realizācijā. Ieguvusi Šveices valdības izcilības stipendiju pētniecībai. Pašlaik ir galvenā izpildītāja Latvijas Zinātnes padomes fundamentālo un lietišḳo pētījumu projektā Vēstures politizācija: postfaktuālās pieejas Latvijas un Krievijas attiecībām XX gadsimtā, instrumentalizācija, izaicinājumi demokrātijai, mācības un pretlīdzekḷi, kā arī ir Latvijas Republikas Saeimas Analītiskā dienesta vadītāja. Veic dažādu politikas jomu analīzi.

Raksturvārdi: zinātnes pārvaldība, zinātniskā darba rezultātu novērtēšana, sociālās un humanitārās zinātnes, zinātnieka karjeras pievilcīgums, zinātniskā personāla ataudze, administratīvais slogs.

\section{Ievads}

Zinātnes, tehnolog̣ijas attīstības un inovācijas pamatnostādnēs 2021.-2027. gadam minētā politikas vīzija ietver "izcilu pētniecību". Latvijas rādītāji zinātnes finansēšanas jomā šobrīd gan neliecina par zinātnes un pètniecības jomas prioritāro statusu - to uzsver ne vien ārvalstu lietpratēji, bet arī vietējās zinātnieku kopienas pārstāvji. ${ }^{2}$ Līdz ar to tiek arī konstatēts, ka politikas plānošanas dokumentos ietvertās ambīcijas un plāni ir vāji savietojami ar realitāti. Latvija regulāri izvirza mērḳi palielināt finansējumu zinātnei, taču rādītāji vairākkārt atpaliek no vēlamā mērķa. Latvijā zinātniski pētnieciskajam darbam paredzētie finanšu līdzekḷi ilgstoši ir bijuši nelieli, un valstij konsekventi tiek izteikti lietpratēju aizrādījumi par pārlieku paḷaušanos uz Eiropas Savienības (ES) fondu līdzekḷiem un ilgstošu nespēju nodrošināt zinātnei pastāvīgu

\footnotetext{
1 Latvijas Republikas Izglitības un zinātnes ministrija 2020b; Latvijas Republikas Ministru kabinets 2021.

2 Sk. Arnold et al. 2014; Kloviņš 2021.
}

nacionālo finansējumu. ${ }^{3}$ Kā redzams 1 . un 2. attēēā, valsts sniegtais atbalsts zinātnei ir ievērojami mazāks nekā tas finansējuma apmērs, kas pieejams ar ES struktūrfondu un citu finanšu instrumentu starpniecību.

Eiropas Savienības attīstības stratēgijā Eiropa 2020 ir izvirzìts pamatmērķis ieguldīt pētniecībā un attīstībā $3 \%$ no ES kopprodukta $^{4}$, savukārt Latvijas nacionālajā reformu programmā Eiropa 2020 stratēgijas īstenošanai noteiktais mērḳis ir palielināt finansējumu pētniecibai līdz 1,5\% no iekšzemes kopprodukta (IKP), bet lìdz 2030. gadam - lìdz 3\% no IKP 5 . Praksē šis rādītājs netuvojas deklarētajām mērķa vērtībām (3. attēls). Šajā ziṇā pasaules līmeña līdervalstis ir Izraēla un Dienvidkoreja (ar rādītāju 4,6\% no IKP 2017. gadā), Šveice $(3,4 \%)$, Zviedrija $(3,3 \%)$ un Japāna $(3,2 \%)^{6}$.

\footnotetext{
3 Arnold et al. 2014; European Commission. 2020a.

4 European Commission 2020b.

5 Latvijas nacionālā reformu programma Eiropa 2020 stratēǵijas īstenošanai. Progresa ziņojums 2017.

${ }^{6}$ UNESCO Institute of Statistics 2019.
} 


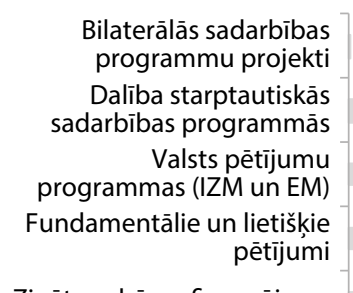

0,3

4,1

4,1

9,5

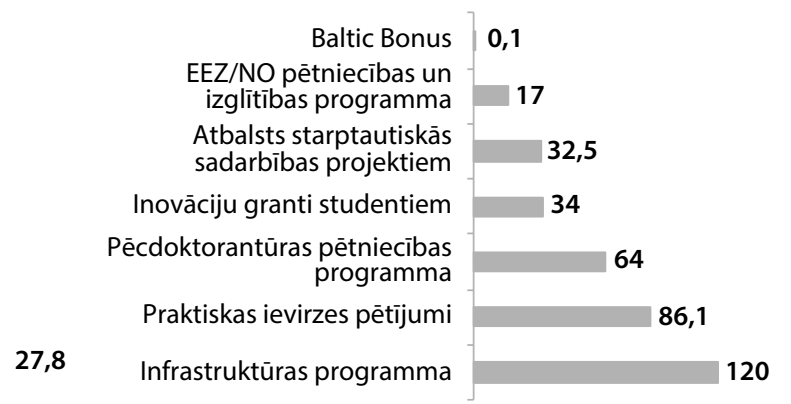

1. attēls. IZM zinātnes programmu finansējums 2019. gadā (milj. eiro)

Avots: Latvijas Republikas Ministru kabinets 2019b

\section{2. attēls. ES struktūrfondu un citu finanšu instrumentu līdzfinansēto zinātnes programmu finansējums no 2014. lìdz 2020. gadam (milj. eiro)}

Avots: Latvijas Republikas Ministru kabinets 2019b

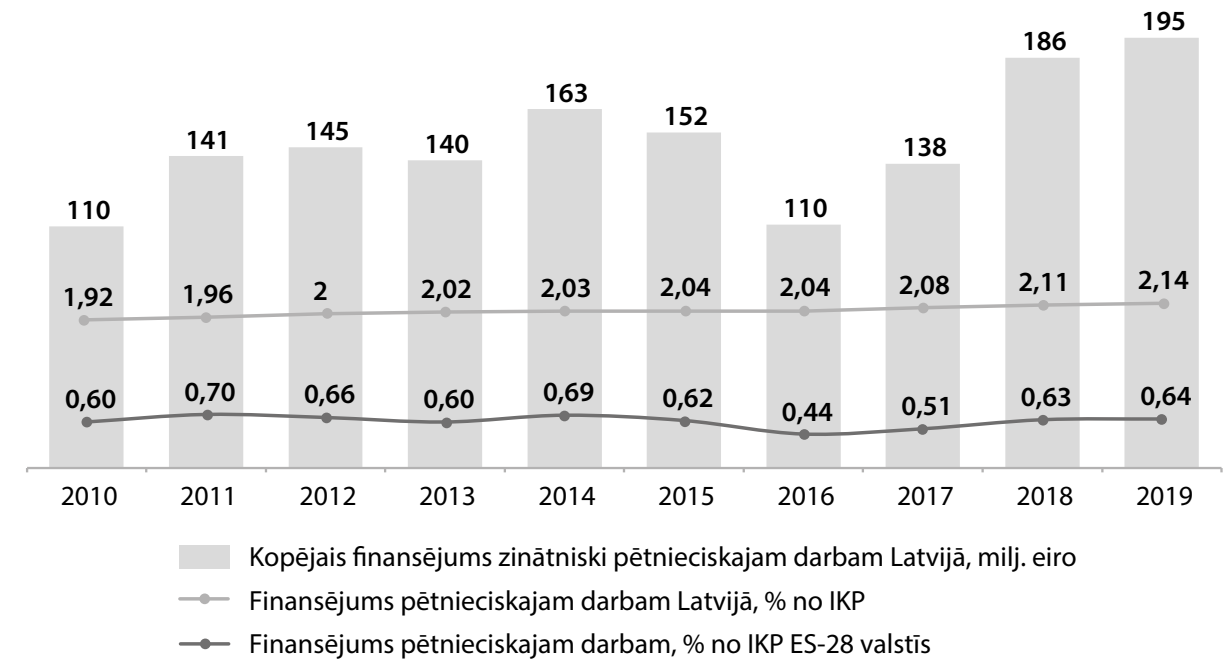

3. attēls. Finansējums zinātniski pētnieciskajam darbam Latvijā un vidēji ES (28 valstīs)

Avots: Eurostat 2021

Neatkarīga zinātnes politikas izpēte Latvijas akadēmiskajā kopienā ir maz veikta, jo sevišḳi pēdējo gadu laikā. Pamatā ar šiem jautājumiem ir strādājuši lietpratēji starptautiskajās institūcijās (Pasaules Banka, Eiropas Komisija [EK]). Šis darbības Latvijas pusē koordinējusi un līdz ar to arī galvenos analizzes akcentus likusi Latvijas Republikas Izglìīibas un zinātnes ministrija (IZM), kas ir atbildīga par šo jomu.

Šà raksta mērḳis ir identificēt un analizēt vairākas problēmas, kas Latvijas zinātnes politikā ir ilgstoši sistēmiski nepietiekami risinātas un kas kombinācijā ar finansējuma trūkumu zinātnei rada bažas par nacionālās zinātnes ilgtspējīgumu. Darba uzdevumi ir raksturot un analizēt zinātniskā personāla ataudzi un faktorus, kas ietekmē karjeras pievilcīgumu; specifiskos humanitāro un sociālo zinātṇu jomas izaicinājumus, kā arī administratīvo veiktspēju un administratīvo slogu, analizzi balstot uz dokumentu analizzes metodes lietojumu. 


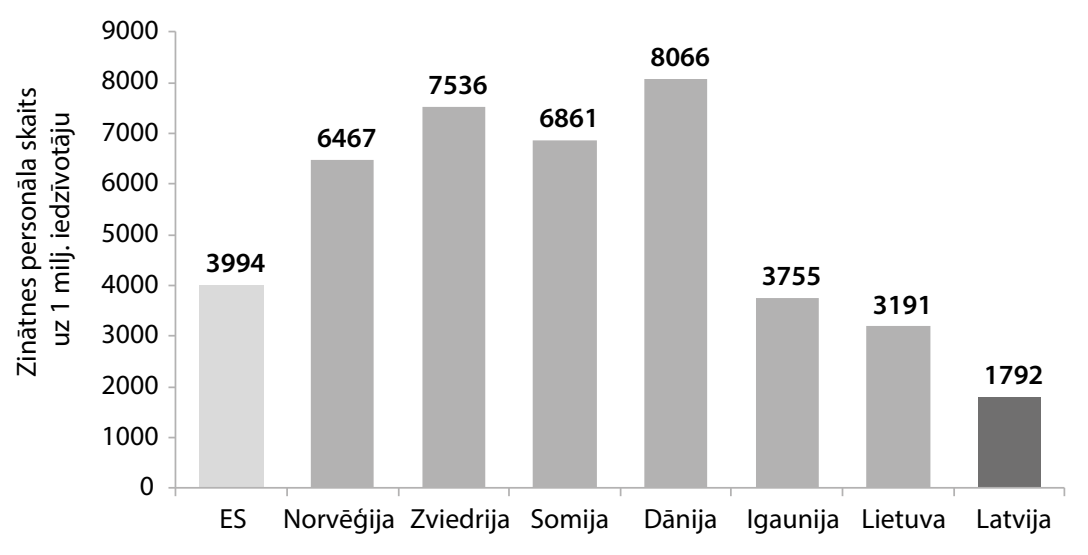

4. attēls. Zinātnisko darbinieku skaits uz 1 milj. iedzīvotāju 2018. gadā

Avots: The World Bank Group 2021

\section{Zinātniskā personāla ataudze un zinātnieka karjeras pievilcīgumu ietekmējošie faktori}

Karjeras prognozējamības trūkums zinātnē ir viena no galvenajām problēmām Latvijas zinātnes pārvaldībā, tās spējā piesaistît un noturēt cilvēkresursus, nodrošināt personāla ataudzi, kā arī uzturēt pētniecības virzienu pēctecîbu.

Jau drīz pēc neatkaribas atgūšanas, 1992. gadā, tika uzsākta Latvijas Zinātņu akadēmijas (LZA) reforma, kuras laikā tās institūti tika iekḷauti universitāšu sastāvā vai arī kḷuva par patstāvīgiem institūtiem ${ }^{7}$. Turpmāko gadu laikā gan nav izdevies skaidri definēt LZA lomu jaunajā situācijā, zinātnieku kopienā un sabiedrībā kopumā. ${ }^{8}$ Pašlaik nav pilnībā skaidrs, kā praktiski tiks istenota iecere par zinātnes un augstākās izglítības integrāciju un ko tas nozīmēs dažādām iesaistītajām pusēm.

Zinātnisko darbinieku (atbilstoši Zinātniskās darbības likumam [ZDL] Latvijā ši kategorija ietver zinātniekus, zinātnes tehnisko personālu un zinātni apkalpojošo personālu ${ }^{9}$ ) skaits uz vienu miljonu iedzīotāju Latvijā ir teju divreiz mazāks nekā kaimiņvalstīs - Igaunijā un Lietuvā -, vairāk nekā divas reizes

\footnotetext{
7 Kloviņš 2021.

8 Veidemane 2020.

9 Latvijas Republikas Saeima 2005.
}

mazāks par vidējo skaitu ES un vairākkārt atpaliek no Ziemeḷvalstu rādītāijiem (4. attēls).

EK lietpratēji karjeras pievilcīguma sekmēšanu minējuši kā stratēgisku ieteikumu Latvijas rīcībpolitikas veidotājiem. Vispārējo situāciju karjeras veidošanā zinātnē raksturo zems algas limenis, nepietiekams lïdzsvars starp darbu un ienākumu stabilitāti, nepietiekami caurskatāma iecelšana un paaugstināšana amatâ ${ }^{10}$. Tādējādi zinātniskā darbība Latvijā nav raksturojama kā konkurētspējiğa, prognozējama un pievilcīga karjeras iespēja nedz pieredzējušiem, nedz arī jauniem zinātniekiem ${ }^{11}$.

Proti, lai gan ZDL noteic ievēlēěanu akadēmiskajos amatos (vadošais pētnieks, pētnieks, zinātniskais asistents) uz sešiem gadiem ${ }^{12}$, bieži vien tādā veidā tiek nostiprināts tikai statuss, no kura neizriet atbilstošas garantijas par atlīdzību. Tādējādi tiek aktualizēts arī jautājums par šo personu sociālajām garantijām. Joprojām bieži sastopama ir prakse zinātniekus nodarbināt nepilnu darba laiku ${ }^{13}$ (5. attēls), tādēl atlīdzỉba ir niecīga un var nepārsniegt pāris simtus eiro.

Latvijas zinātnes bāzes finansējums aizvien tiek izmaksāts ievērojami mazākā apmērā,

\footnotetext{
${ }^{10}$ Eiropas Komisija 2020.

${ }^{11}$ Latvijas Republikas Izglìtības un zinātnes ministrija 2020e.

${ }^{12}$ Latvijas Republikas Saeima 2005.

${ }^{13}$ Sk. Darba sludinājumi Latvijas Universitātē.
} 


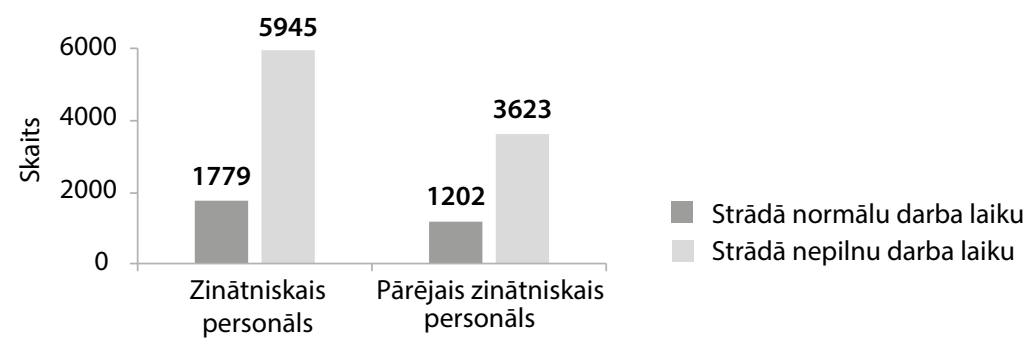

\section{5. attēls. Zinātniski pētnieciskajā darbā normālu un nepilnu darba laiku strādājošo skaits Latvijā 2019. gadā}

Avots: Centrālā Statistikas pārvalde 2020

nekā aprēḳināts saskaņā ar normatīvo regulējumu ${ }^{14}$ - 2021. gadā tas tiks pieškiirts tikai $39,63 \%$ apmērā no aprēḳinātā ${ }^{15}$, kas ir mazāk nekā 2020. gadā $(44,31 \%)^{16}$. Turklāt zinātniskā personāla atlīdzība ir tikai viena no izmaksu pozīcijām, kam zinātniskās institūcijas izmanto bāzes finansējumu ${ }^{17}$.

Tādējādi tas, vai par zinātnisko darbību būs pienācīga samaksa, galvenokārt atkarīgs no sekmīguma zinātnisko projektu konkursos. Lìdz ar to zinātnieki tiek pakḷauti neprognozējamiem zinātniskā darba pārtraukumiem, kas bieži vien nozìmē pētījumu apraušanos vai pētniecibas virziena main̦u. Turklāt Latvija saṇēmusi norādes par to, ka būtu jāpārskata uz konkurenci balstītā piešksirtā finansējuma nosacījumi, lai zinātnieki varētu uzṇemties ilgtspējīgākas saistības karjerā (piem., lielākus un ilgākus projektus $)^{18}$. Pašlaik viens no galvenajiem Latvijas zinātnieku darbības finansēšanas avotiem no valsts budžeta ir Latvijas Zinātnes padomes (LZP) fundamentālo un lietiškso pētỉjumu (FLP) projektu finansējums. Tieši šì finansēšanas programma gūst ievērību arī tādēl, ka tā ir vienīgā Latvijā, kas vispilnīgāk ḷauj îstenoties akadēmiskajai brīvībai. Proti, atškirīīā no valsts pètījumu programmām (VPP), kur pètījumu tēmas pasūta valsts un tematiskais

14 Latvijas Republikas Ministru kabinets 2013a.

15 Latvijas Republikas Izglìīibas un zinātnes ministrija 2021b.

16 Latvijas Republikas Izglītības un zinātnes ministrija 2020g.

17 Latvijas Republikas Ministru kabinets 2013a.

18 Eiropas Komisija 2020. fokuss līdz ar to ir reglamentēts, FLP projektu pieteikumu konkursā zinātnieki paši piedāvā pētāmās tēmas sešās zinātṇu nozaru grupās (tas ir tā dēvētais augšupvērstais (angl. bottomup) princips). Tātad FLP ir publiskais finansējums, kas ḷauj attīstìt zināšanu bāzi un tādējādi nodrošināt pēctecību visās zinātnes nozarēs.

FLP finansējums tiek piešķirts 36 mēnešu periodam $^{19}$. Šāds projekta īstenošanas termiņš visbiežāk noteikts arī citās finansējuma programmās, citstarp no ES fondiem finansētajās programmās (piem., pēcdoktorantūras pētniecíbas atbalsts ${ }^{20}$ vai praktiskas ievirzes pētījumi ${ }^{21}$ ), taču mēdz būt arī ìsāks (piem., 2018. gada otrajā konkursā finansējums tika pieškirts vien divu gadu ${ }^{22}$ periodam). Tas, ka praksē šāds apmaksāts darbības periods projektā var nebūt pietiekams zinātniskās ieceres pilnīgai īstenošanai, atzìts gan, piem., VPP projektu īstenošanas kārtībā ${ }^{23}$, gan arī FLP projektu konkursa nolikumā ${ }^{24}$. Proti, tiek piel̦auta iespēja projekta īstenošanas laiku pagarināt uz periodu līdz 12 mēnešiem, taču piešķirtais finansējums pagarinājuma periodā netiek palielināts. Šāds risinājums būtībā leg̣itimē neapmaksātu darbu zinātnē, ar ko realitātē sastopas daudzi zinātnieki. Būtu jāattīsta elastīgāka pieeja, kas l̦autu turpināt projektus, kuri atzìti par veiksmīgiem, nepārtraucot to

\footnotetext{
19 Latvijas Zinātnes padome 2018a.

20 Latvijas Republikas Ministru kabinets 2016b.

21 Latvijas Republikas Ministru kabinets 2016a.

22 Latvijas Universitāte 2018.

23 Latvijas Republikas Ministru kabinets 2018.

24 Latvijas Zinātnes padome 2018a.
} 


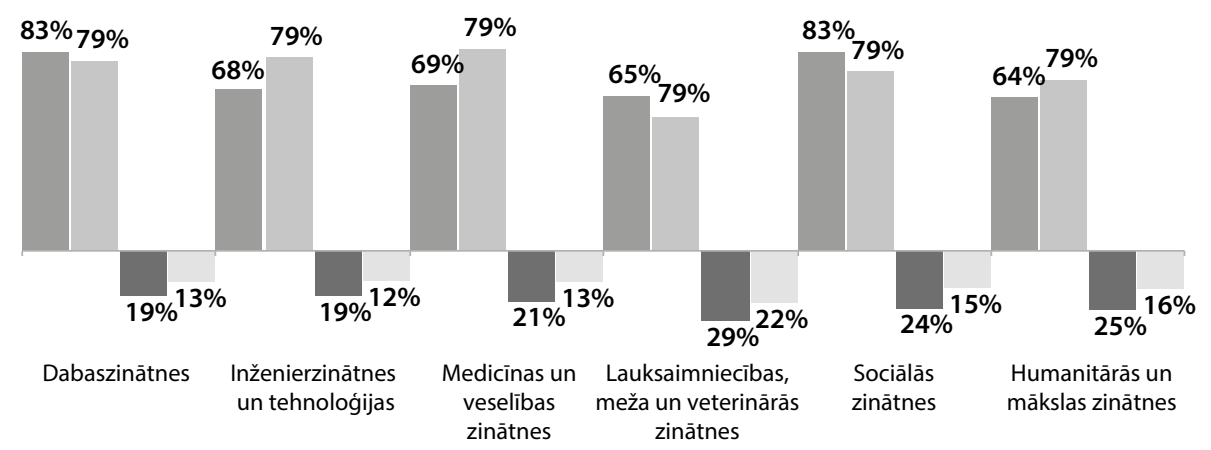

Virs kvalitātes sliekšn,a novērtētie projekti, 2018

Virs kvalitātes sliekšña novērtētie projekti, 2020

Finansētie projekti no virs kvalitātes sliekšña novērtētajiem, 2018

Finansētie projekti no virs kvalitātes sliekšn,a novērtētajiem, 2020

\section{6. attēls. To FLP programmā iesniegto projektu īpatsvars (\%), kuri novērtēti virs kvalitātes sliekšņa, un finansēto projektu īpatsvars (\%) no virs kvalitātes sliekšņa novērtētajiem 2018. un 2020. gadā}

Avots: Latvijas Zinātnes padome 2018b; Latvijas Zinātnes padome 2020

finansēšanu. Tomēr šādā gadījumā l̦oti svarīgi, lai atzinumu par projektu turpināšanas nepieciešamību sniegtu vienīgi neatkarīgi ārvalstu eksperti. Nav piel̦aujama situācija, ka zinātnieku darba kvalitāti vērtē zinātni administrējošo institūciju darbinieki, kuriem nav tam atbilstošas kvalifikācijas (tātad nav iespējams ievērot tā dēvēto ekspertu kontroles (peer review) principu), vai arī projektu zinātnisko grupu dalībnieku kolēǵi vietējā zinātnes vidē, piem., LZP ekspertu komisiju locekli i ${ }^{25}$.

Konkurence par zinātnisko projektu finansējumu ir sīva. FLP programmā lielai daļai virs kvalitātes sliekšna novērtēto projektu pieteikumu netiek pieškirts finansējums, jo tas ir ierobežots (6. attēls). Finansējuma apjoms šiem projektiem pēdējo gadu laikā gan ir audzis ${ }^{32}$, taču tas vēl aizvien nav pietiekams.

Kvalitatīva pieteikuma izstrāde tāpat kā projektu konkursam saṇemto pieteikumu vērtēšana var aizñemt daudz laika - šis cikls var ilgt teju gadu ${ }^{26}$-, taču nedz projektu pieteikumu gatavošanas laiks, nedz laiks, kamēr tiek gaidīti konkursa rezultāti, netiek apmaksāts. Tātad pretendentiem ir jābūt finansiāli patstāvīgiem

25 Latvijas Republikas Ministru kabinets 2019a.

26 Latvijas Zinātnes padome 2021. vai ar neatkarīgu ienākumu gūšanas veidu. Minētie faktori darbību zinātnē var padarìt par sekundāru nodarbi, kas savukārt var negatīvi ietekmēt zinātniskā darba kvalitāti.

Reagéjot uz EK lietpratēju kritiku par garantētas nodarbinātības modeḷa neesību, kā arī personāla vēlēšanu sistēmas necaurskatāmību ${ }^{27}, 2020$. gadā vērojama pozitīva tendence - tika uzsākta virzība uz tenūras (beztermiṇa darba līgumu) sistēmas ieviešanu ${ }^{28}$. IZM apṇēmusies šo akadēmiskā un zinātniskā personāla motivācijas un nodarbinātības sistēmu ieviest, sākot ar 2022. gadu. Paredzēts, ka vēlētais personāls, iegūstot noteiktu amatu, kā arī demonstrējot atbilstību noteiktiem kritērijiem, varēs ieņemt tenūramatu jeb slēgt beztermiña darba līgumu. Pašlaik līgums ir terminēts, proti, tiek slēgts uz sešu gadu periodu, ${ }^{29}$ un tas darbu zinātnes jomā dara neprognozējamu. Ir būtiski, lai iespēja saglabāt amatu ilgāk par sešiem gadiem tiktu sniegta kopā ar garantijām par prognozējamu atlīdzību.

27 Eiropas Komisija 2020.

28 Latvijas Republikas Izglītības un zinātnes ministrija 2020d.

29 Latvijas Republikas Izglītības un zinātnes ministrija 2020h. 
Pēdējo desmit gadu laikā liels uzsvars likts uz jauno zinātnieku skaita palielināšanu. Tas ietverts arī aktuālajā Latvijas Nacionālajā attīstības plānā 2021.-2027. gadam (NAP) ${ }^{30}$. No vienas puses, šie centieni ir pamatoti. Kā norāda EK, jaunu doktorantūras programmu absolventu piesaistǐšana un noturēšana ir viena no galvenajām problēmām, ar kurām saskaras Latvijas augstākās izglìtības un pētniecības un inovāciju sistēmas. ${ }^{31}$ No otras puses, veidojas apburtais loks. Situācijā, kad nav iespējams nodrošināt finansējumu pieredzējušiem zinātniekiem, centieni palielināt jauno zinātnieku skaitu ar finansiāliem stimuliem un administratīviem kritērijiem (piem., jauno zinātnieku dalïbas kvota projektos ${ }^{32}$ ) var maldināt, radot ilūziju par progresu, kaut arī jauno zinātnieku nākotnes karjeras izredzēm vēlākajos karjeras posmos netiek veidoti labvēlīgi priekšnoteikumi.

Būtu jāvairās no tādiem politikas un finansēšanas risinājumiem, kas, iespējams, veicina noteiktu rādītāju uzlabošanos īstermiṇā, taču neiekḷaujas plašākā sistēmiskā ilgtermiṇa risinājumu programmā. Mēginājumi panākt akadēmiskā personāla atjaunošanos, palielinot jauno doktoru un pēcdoktorantu skaitu, nav mērķtiecīgi, ja nav atbilstoša bāzes finansējuma un pietiekama zinātnisko projektu finansējuma, kas spētu nodrošināt speciālistu tālāku pastāvīgu darbošanos zinātnē. Arī ārvalstu lietpratēji prognozējuši, ka jaunajiem zinātniekiem stabili ienākumi nav paredzami, un tas liek tiem strādāt ārpus akadēmiskā darba ${ }^{33}$. Lìdz ar to politikas plānotājiem un lēmumu pieñēmējiem šì sociālā realitāte ir jārespektē un institūcijām jāpiedāvā gan, piem., elastīgi nodarbinātības nosacījumi, gan citi risinājumi. Lai arī pēcdoktorantūras pētniecības atbalsta deklarētais mērḳis ir nodrošināt jaunajiem zinātniekiem iespēju uzsākt karjeru zinātniskajās institūcijās ${ }^{34}$, realitātē var tikt panākts pretējs efekts, proti, var tikt veicināts bezdarbs un emigrācija, kuras pamatā ir neīstenotās gaidas par karjeras perspektīvām. Arī EK lietpratēji

30 Pārresoru koordinācijas centrs 2020.

31 Eiropas Komisija 2020.

${ }^{32}$ Latvijas Zinātnes padome 2019.

33 Eiropas Komisija 2020.

${ }^{34}$ Latvijas Republikas Ministru kabinets 2016 b. norāda, ka zinātniskā personāla novecošanu veicina citstarp atlases, nodarbinātības nosacijumi un noteikumi par paaugstināšanu amatā $^{35}$. Tātad, nerisinot problēmu kompleksi, zinātniskā personāla atjaunotne nenotiks.

Aprēḳini liecina: Latvijā pētniecībā un attīstībā ieguldīto līdzekḷu apmērs, rēḳinot uz vienu zinātnisko darbinieku, tikai nedaudz pārsniedz ceturtdaḷu no ES vidējā rādītāja, kas ir 105568 eiro. Savukārt 2018. gadā Latvijā tie bija 30833 eiro jeb $29 \%$ no ieguldījumu summas, kas vidēji ir ES. Tomēr, neskatoties uz nelielajiem ieguldijumiem, Latvijas zinātnē vērojama augsta veikto ieguldijumu efektivitāte - ar ievērojami mazākiem ieguldījumiem tiek sasniegti tādi pētniecības rezultāti, kas līdzvērtīgi citu ES valstu kolẹgu sasniegtajiem rezultātiem ${ }^{36}$. Piem., ar četrkārt mazākām kopējām izmaksām nekā vidēji ES Latvijas zinātnieki spēj izstrādāt datubāzē Web of Science indeksētas publikācijas. Valstij ir jārēḳinās ar to, ka notiks "smadzenuu aizplūšana". Pasaules līmenī strādājošiem Latvijas zinātniekiem ilgtermiṇā nebūs pievilcīgi tie pieticīgie apstākḷi, ko piedāvā zinātnes vide Latvijā. Arī Latvijas diasporas zinātniekiem, kuri apsver sadarbību ar zinātniekiem Latvijā, primāri ir pragmatiskie, nevis emocionālie apsvērumi. Tiek sagaidīts, ka šì nozare Latvijā būs labi finansēta, pārvaldìta un balstīta uz sasniegumiem ${ }^{37}$.

Līdz šim ievērojama publiskā finansējuma daḷa tikusi sadalīta dažādiem infrastruktūras (jo sevišksi ēku) projektiem ${ }^{38}$. Tam pievērst uzmanību Saeimas deputātus aicinājusi arī Latvijas Izglìtíbas un zinātnes darbinieku arodbiedrība ${ }^{39}$. Pašlaik, ṇemot vērā tās izmaiṇas darba organizācijā (attālinātais darbs), kuras ieviesusi Covid-19 pandēmija, lielāks uzsvars būtu liekams uz zinātniskā darba samaksu.

Iepriekš izklāstītās problemātikas kontekstā piesardzīgi vērtējams Latvijas Nacionālajā attīstības plānā 2021.-2027. gadam no iepriekšejiem periodiem saglabātais uzsvars, proti,

\footnotetext{
${ }^{35}$ Griniece, Nausedaite 2017.

${ }^{36}$ Latvijas Republikas Ekonomikas ministrija 2020.

37 Bela et al. 2018.

38 Latvijas Republikas Izglìtības un zinātnes ministrija 2016.

39 Orupe 2019.
} 
nepieciešamība piesaistīt ārvalstu pētniekus "zinātniskā personāla paaudžu nomaiņai un pètniecíbas un attīstîbas apjoma un daudzveidības palielināšanai" ${ }^{40}$. Valdības atbalstītajā sarakstā starp specialitātēm, kurās darbā var tikt uzaicināti ārzemnieki, ir iekḷauti zinātnieki ${ }^{41}$, taču Latvijas valsts budžetā zinātnei atvēlētā finansējuma ietvaros iespējams realizēt daudz mazāk augstas kvalitātes pētniecisko ideju, nekā Latvijas zinātnieki ir spējīgi piedāvāt. Tātad Latvijā ir pietiekami daudz zinātnieku, kuri var tikt nodarbināti ne vien valsts, bet arī privātajā sektorā. Turklāt, kā jau iepriekš norādīts, zinātniskā personāla paaudžu maiṇu kavē ne tik daudz speciālistu un to kvalifikācijas trūkums, cik nespēja tiem piedāvāt pievilcīgus karjeras nosacījumus. Vienlaikus, atzīstot internacionalizācijas kā svarīgas zinātnes procesa dimensijas lomu, būtiski šajā kontekstā ir vērtēt arī ārvalstu pētniekiem paredzamos nodarbinātības nosacījumus, primāri ar to domājot atlīdzības griestus. Nosakot tos labvēlīgākus nekā Latvijas pētniekiem, Latvijas speciālisti tiktu ierindoti zemākā pozịcijā.

\section{Specifiskie sociālo un humanitāro zinātṇu izaicinājumi}

Kopumā aizvadītajā gadu desmitā zinātnes politikas plānošanā uzsvērta zinātnes instrumentalizācijas nepieciešamība, lai uzlabotu tautsaimniecības konkurētspēju. ${ }^{42}$ Šis uzsvars kā finansējuma piešķiršanas kritērijs reproducēts arī dažādās zinātniskās darbības finansēšanas programmās (piem., pēcdoktorantūras pētniecības atbalsts un praktiskas ievirzes pētījumi) ${ }^{43}$. ES fondu līdzekḷi prioritāri tiek virzīti zinātniskajam darbam, kas saistīts ar tā dēvētajām viedās specializācijas jomām, par kurām līdz šim Latvijā bija noteikta zināšanu ietilpīga bioekonomika (inovatīva mežu audzēšana, koksnes izmantošana, augu un

${ }^{40}$ Pārresoru koordinācijas centrs 2020.

${ }^{41}$ Latvijas Republikas Ekonomikas ministrija 2018.

${ }^{42}$ Latvijas Republikas Saeima 2010; Pārresoru koordinācijas centrs 2020; Valsts izglìtïbas attīstības aǵentūra 2020.

${ }^{43}$ Latvijas Republikas Ministru kabinets 2016a; Latvijas Republikas Ministru kabinets 2016b. dzīvnieku audzēšana un pārstrāde, pārtikas drošiba); biomedicīna, medicinas tehnologiijas, biofarmācija un biotehnologijas; viedie materiāli, tehnologiijas un inženiersistēmas; viedā enerḡêtika; informācijas un komunikācijas tehnologijas ${ }^{44}$. Arī turpmākajā periodā no 2021. gada līdz 2027. gadam IZM nesaskata nepieciešamību ieviest kādas korekcijas minēto jomu uzskaitījumā ${ }^{45}$. ES fondu līdzekḷi bieži vien tiek ieguldīti arī infrastruktūras attīstībā. Jomas lietpratēji atzīst - lielā mērā tieši pateicoties zinātniskās infrastruktūras attīstībai, panākts būtisks publikāciju skaita pieaugums Latvijā ${ }^{46}$. Tomēr šis apstāklis vienlaikus palielina dabaszinātņu priekšrocības, ņemot vērā to, ka ieguvumus no infrastruktūras uzlabojumiem visvairāk saṇem tieši dabaszinātṇu pārstāvji, bet salīdzinājumā ar sociālajām un humanitārajām zinātnēm (SHZ) tai ir sekundāra loma iepretī daudz svarīgākajai nepieciešamībai ieguldīt cilvēkresursos, precīzāk, to atlīdzībā.

Jau 20. gs. 90. gadu sākumā iezīmējās izteikta nevienlīdzība zinātnes nozaru finansējuma sadalījumā ${ }^{47}$. Vēlāk, laikā no 2006. gada līdz 2009. gadam, tika istenota VPP Letonika, pēc tam - VPP Nacionālà identitāte (valoda, Latvijas vēsture, kultūra un cilvēkdrošìba) (2010-2013), taču tā bija vienīgā no piecām VPP, kas bija veltìta SHZ. Šajā periodā arī starp valstī noteiktajiem prioritārajiem virzieniem FLP finansēšanai tikai viens bija saistîts ar SHZ ${ }^{48}$. Aizvadìtajā desmitgadē SHZ pētỉjumiem atvēlētais LZP finansējums proporcionāli bijis zems - aptuveni viena sestdaḷa no finansējuma, ko saṇēmušas citas nozares (biologija, medicīna, lauksaimniecība un meža zinātne). Savukārt laikā, kad par LZP prioritārajām zinātnes nozarēm bija noteiktas informācijas tehnologiijas, organiskā sintēze un biomedicīna, materiālzinātnes, medicīna, vides zinātne un agrobiotehnoloǵija, SHZ nebija šo nozaru vidū. Tas ìpaši uzsvērts pēc EK pieprasījuma

\footnotetext{
44 Krumberga 2018.

45 Latvijas Republikas Izglītības un zinātnes ministrija 2020a.

46 Klovin̦š 2021.

47 Stradiņš 1995.

48 Latvijas Republikas Ministru kabinets 2009.
} 
gatavotā ziṇojumā par SHZ stāvokli Latvijā. ${ }^{49}$ Redzams, ka SHZ attīstību ilgstoši negatīvi ir ietekmējuši sistēmiski un institucionāli nosacìti faktori un tās funkcionējušas lielā mērā nelabvēlīgā vidē. Turpmāk, neveidojot šìm zinātnes nozarēm ìpaši labvēlīgus apstākḷus, to pozīcijas un cilvēkresursi ar katru gadu aizvien vairāk tiks novājināti. Pašlaik IZM īstenoto VPP proporcija starp SHZ un dabaszinātnēm ${ }^{50}$ ir ar pozitīvu dinamiku.

Prakse izmantot zinātnes sasniegumu noderīgumu tirgū kā pamatrādītāju, nosakot prioritārās nozares un vajadzību tās attīstīt un tajās ieguldìt, ir riskanta. Zinātnes uzdevumi sabiedrībā būtu jāskata daudz plašākā kontekstāa ${ }^{51}$, turklāt jāatceras, ka valsts pasūtijumu zinātnē jeb valsts pētījumu programmas ${ }^{52}$, pamatojoties uz 2018. gada 28. jūnija grozījumiem $^{53} \mathrm{ZDL}^{54}$, ir tiesīgas veidot, isstenot un finansēt nozaru ministrijas atbilstoši katras nozares prioritātēm. Tas var veiksmīgi risināt specifiskas nozares problēmas un nodrošināt vajadzīgo zināšanu pārnesi no akadēmiskās kopienas pie attiecīgās nozares politikas veidotājiem iespējami nepastarpināti. Pagaidām gan šì iespēja vēl netiek plaši izmantota ${ }^{55}$. IZM budžetā paredzētā zinātniskās darbības finansējuma sadalījumā būtu pēc iespējas jādemonstrē iekḷaujoša pieeja attiecībā uz visām zinātnes nozaru grupām, īpaši akcentējot tieši FLP finansēšanu un bāzes finansējuma palielināšanu.

Par SHZ neizdevīgo stāvokli salīdzinājumā ar dabaszinātnēm liecina arī dominējošā un samērā unificētā pieeja zinātniskā darba rezultātu novērtēšanai. Gan Latvijas zinātnes kopienas pārstāvji, gan Valsts prezidents Egils Levits ir aicinājuši pievērst uzmanību tam, ka SHZ un dabaszinātnes ir sarežgìiti vērtēt

49 Metris 2011.

50 Latvijas Republikas Izglītības un zinātnes ministrija 2020i.

51 Karnīte 2019; Shah 2020.

${ }^{52}$ Latvijas Republikas Ministru kabinets 2018.

53 Latvijas Republikas Saeima 2018.

54 Latvijas Republikas Saeima 2005.

55 Latvijas Republikas Izglìtības un zinātnes ministrija 2021a. pēc identiskiem kritērijiem ${ }^{56}$. Šì problemātika pēdējā gadu desmitā aizvien vairāk nostiprinās arī globālajās akadēmiskajās diskusijās. Lietpratēji aicina katras nozares vērtējumam par pamatu ņemt tās sabiedrisko funkciju un respektēt specifiskos saziṇas kanālus, kādi nepieciešami šis funkcijas ìstenošanai. Pretrunīgi tiek vērtēta, piem., ierastā ietekmes faktora izmantošana centienos novērtēt zinātniskā darba kvalitāti. Ir norādīts, ka starpdisciplinārus pētijumus, kas nereti ir novatoriski, nav iespējams atbilstīgi izmērīt, lietojot tādu vērtēšanas sistēmu, kas balstīta uz konkrētām nozarēm. Arī citējumu uzskaitī̌sanai kā zinātnes sasniegumu kvalitātes indikatoram var piemist būtiski ierobežojumi - kā kvantitatīva metode tā drīzāk mēra pētījuma popularitāti. Citējumu uzskaitīšanas pieeja var radìt priekšrocības konvencionālajai pētniecībai un jau iedibinātām paradigmām. Tādi pētījumu rezultāti, kas izaicina dominējošās tendences, ne vienmēr zinātniskajā kopienā tiek uzreiz ievēroti, turpretī tādi, kas rada pamatu kritikai vai pat tiek atspēkoti, var saṇemt lielu citējumu skaitu, kas šādā gadījumā neliecina par zinātniskā snieguma kvalitāti. Mūsdienu diskusijas aktualizē zinātniskā darba kvantitatīvā novērtējuma trūkumus, aicinot novērtējumā vairāk integrēt kvalitatīvo dimensiju. Latvijā gan l,oti iesakņojusies kvantitatīvā pieeja, liekot uzsvaru uz žurnālu rakstu un citējumu uzskaitījumu ${ }^{57}$, ko stimulē arī aktuālās finansēšanas programmas. Piem., starp valsts pètījumu programmu, kā arī pēcdoktorantūras un praktiskas ievirzes pētījumu programmas iznākuma rādītājiem figurē zinātniskie raksti ${ }^{58}$, bet ne zinātniskās monogrāfijas, kas klasiski uzskatāms par brieduma rādītāju zinātniskajā darbā, jo sevišķi SHZ pārstāvjiem. Globālajā akadēmiskajā kopienā regulāri izskan aicinājumi un tiek sniegts pamatojums nepieciešamībai integrēt zinātniskā darba novērtējumā tādus zinātniskā darba kvalitātes kritērijus, kas respektē zinātnes

\footnotetext{
56 Karnite 2019; Latvijas Valsts prezidenta kanceleja 2020.

57 Sk. Bažbauers, Kurzemniece 2014; Latvijas Republikas Ministru kabinets 2013b.

58 Latvijas Republikas Ministru kabinets 2018; Latvijas Republikas Ministru kabinets 2016a; Latvijas Republikas Ministru kabinets 2016b.
} 
nozaru specifiku, to sabiedrisko funkciju un specifiskos saziņas kanālus, kādi nepieciešami attiecīgās funkcijas īstenošanai. SHZ lielā mērā ir piesaistītas vietējam kontekstam gan pètījumu priekšmeta, gan mērķauditorijas ziṇā, līdz ar to ir pieṇemami, ka tām SHZ nozarēm, kas ipaši koncentrējas uz problēmām pašu sabiedrībā, primārā foruma valoda ir attiecīgās valsts valoda. Jārespektē fakts, ka SHZ pētījumiem būtiski ir sasniegt ne vien akadēmisko kopienu, bet arī plašāku mērķauditoriju, tostarp gan publiskās valsts varas institūcijas (lai sekmētu uz pierādījumiem balstītas politikas veidošanas un lēmumu pieņemšanas praksi), gan arī sabiedrību kopumā. ${ }^{59}$

Pienākumu uzrunāt minēto auditoriju citstarp noteic ZDL 6. panta otrais, trešais un sestais punkts ${ }^{60}$. SHZ loma dažādu sabiedrisku parādību un procesu skaidrošanā sabiedrībā ir īpaši aktuāla mūsdienu sociālās realitātes un izaicinājumu kontekstā, ko mēdz apzīmēt par "pēcpatiesības" ${ }^{61}$ laikmetu. Viens no 20. gs. izcilākajiem Latvijas zinātniekiem akadēmiķis Jānis Stradiņš šajā kontekstā ir norādījis uz zinātnes funkciju plašā izpratnē, proti, uzturēt "kritisku un brīvdomīgu gaisotni" sabiedrībā ${ }^{62}$. Arī aktuālajā zinātniskajā literatūrā par tā dēvēto universitāšu "trešo misiju" autori aicina politikas veidotājus un zinātniskās institūcijas vairīties no izomorfisma jeb centieniem gūt iespējami augstu pozīciju ranžèjumos. Tā vietā būtu vairāk jānovērtē SHZ specifiskais pienesums, proti, sabiedrības izpratnes veicināšana par ekonomiskās un sabiedriskās dzīves sarežgìîîu, kā arī ieguldījums tā dēvētās zinātnes pratības (scientific literacy) veicināšanā. $\mathrm{Ne}$ velti dažādos konkursos par finansējumu projektu pieteikumu iesniedzējiem jāspēj zinātnisko ieceru izklāstā pamatot tēmas sabiedrisko nozìmīgumu un ietekmi. Pozitīvi vērtējams tas, ka arī FLP projektu konkursos šì komponente veido visai augstu īpatsvaru kopējā vērtējumā.

59 Sk. Arnold et al. 2014; Bonaccorsi 2018; Billiet et al. 2004; DORA 2012; Jahn 2017; Karnite 2019; Marx, Bornmann 2013; Ochsner et al. 2012; University of Oulu 2021; Spaapen 2007; Toledo 2018.

${ }^{60}$ Latvijas Republikas Saeima 2005.

${ }^{61}$ McIntyre 2018.

${ }^{62}$ Stradiņš 1995.
Šā iemesla dēḷ ipaši būtiski ir finansēt SHZ jomas pētijumus no valsts budžeta, tādējādi palīdzot izvairīties no privāto interešu, politisko vēlmju vai noteiktu interešu grupu aktuālo jautājumu ietekmes pētniecībā.

N̦emot vērā iepriekš minēto, par īpaši veiksmīgu var uzskatīt pašlaik praktizēto FLP projektu pieteikumu izvērtēšanas kārtību, kas paredz starptautisko ekspertu piesaisti projektu kvalitātes izvērtēšanai ${ }^{63}$. Šāda kārtība gan ir spēkā tikai kopš 2017. gada, tomēr tā būtu jāizkopj arī turpmāk, pēc iespējas izvairoties tajā integrēt agrāk izmantoto izvērtēšanas praksi, proti, ka projektu iesniegumus izvērtē vietējie zinātnieki, kas būtībā ir pretendentu kolēgi un vienlaikus arī konkurenti. Tik šaurā zinātnes vidē, kāda tā ir Latvijā, ievērot pilnīgu neitralitāti un pieṇemt no interesēm brīvus lēmumus ir nopietns pārbaudijums.

\section{Administratīvā veiktspēja un administrativais slogs}

Raksturojot Latvijas zinātnes pārvaldību, novērtējumos citstarp lietoti tādi apzīmējumi kā "smagnējas birokrātiskās tradīcijas" un "vāja administratīvā veiktspēja" ${ }^{4}$. 2017. gadā arī EK lietpratēji norādīja uz zinātni administrējošo institūciju ierobežoto spēju veidot, ieviest un koordinēt pētniecības un inovāciju politiku ${ }^{65}$. Politikas pasākumu efektivitāti citstarp slāpē sistemātiska novērtējuma trūkums. To veicot, savlaicīgi būtu iespējams gūt pierādījumu bāzi par tām nepieciešamajām darbībām, kas potenciāli varētu korigêt pasākumus, kuri nav pietiekami efektīvi. Aicinājumi veikt IZM funkcionālo auditu, atbrīvojot ministriju no politikas ieviešanai nevajadzīgām funkcijām ${ }^{66}$, izskanējuši jau vairāk nekā pirms gadu desmita, un šādas darbības būtu periodiski jāatkārto, lai iespējami lietderīgi izmantotu pieejamos resursus.

Latvijas zinātnes pārvaldības sadrumstalotības mazināšana ir gan lietpratēju rekomendēta, gan apstiprināta vietējā līmenī, ietverot

${ }^{63}$ Latvijas Republikas Ministru kabinets 2017a.

${ }^{64}$ Arnold et al. 2014.

${ }^{65}$ Griniece, Nausedaite 2017.

${ }^{66}$ Latvijas Valsts prezidenta kanceleja 2009. 
to valdības deklarācijāa ${ }^{67}$. Par progresu šis sadrumstalotības mazināšanā šḳietami liecināja Latvijas Zinātnes padomes izveide uz lìdzšinējo divu institūciju - LZP un Studiju un zinātnes administrācijas (SZA) - bāzes ${ }^{68}$. Tomēr ir svarīgi, lai konsolidācija būtu ne vien uz procesu, bet arī uz rezultātu orientēta darbība. Ir nepieciešama funkciju pārlūkošana, lai panāktu praktiskus uzlabojumus. Vērtējot SZA darbību, Valsts kontrole secinājusi, ka kopš iestādes izveides nebija vērtēta pamatfunkciju turpmākas nodrošināšanas nepieciešamība ${ }^{69}$. Ir svarīgi sekot līdzi tam, lai šāda prakse netiktu turpināta jaunizveidotajā iestādē. Pagaidām gan ir maz liecību par to, ka virzỉba uz šo mērḳi vainagotos ar panākumiem. Jaunizveidotā LZP ir pārmantojusi vairākas diskutablas funkcijas, kas zinātniskajam darbam rada administratīvo slogu. Piem., ar LZP saskan,ojamas noteikta apmēra skaitliskās izmaiņas zinātniskajā grupā, kā arī projekta galveno izpildìtāju main, ${ }^{70}$ Tā var tikt uzskatīta par birokrātisku iejaukšanos zinātnieka - grupas vadītāja - akadēmiskajā brīvībā pašam veidot zinātnisko grupu. Diemžēe šādi signāli liecina par formālu pieeju zinātnes pārvaldības pilnveidošanai. Kopumā Latvijas zinātni administrējošo institūciju potenciāls pašlaik tiek izlietots galvenokārt kontroles funkciju isstenošanai, savukārt atbalsta mehānismu trūkst.

Īpaši būtu apsverami risinājumi, kas ḷautu vismaz daḷu zinātnei atvēlētā finansējuma izmaksāt zinātniekiem nepastarpināti, procesā iesaistot iespējami maz starpnieku, kas pašsaprotami rada arī liekas izmaksas. Viens no iespējamiem risinājumiem - piesaistìt zinātnei paredzēto valsts finansējumu nevis zinātniskajām institūcijām, kas pašlaik ir galvenās zinātnisko projektu finansējuma saņēmējas, bet gan zinātniskajām grupām vai individuāliem zinātniekiem tiešā sadarbībā ar LZP. Vērtīgu

${ }^{67}$ Griniece, Nausedaite 2017; OECD 2019; European Commission 2019; Deklarācija par Artura Krišjāṇa Kariṇa vadītā Ministru kabineta iecerēto darbību 2019.

68 Latvijas Republikas Ministru kabinets 2019 b.

69 Latvijas Republikas Valsts kontrole 2017.

70 Latvijas Zinātnes padome 2018a; Latvijas Republikas Ministru kabinets 2018; Latvijas Republikas Ministru kabinets 2017a. pieredzi darbībai pēc šāda model̦a var sniegt Dānijā aprobētā prakse piešķirt grantus zinātniskajam darbam ${ }^{71}$ vai, piem., pieeja, kas tiek lietota Eiropas sadarbībā zinātnes un tehnologiju jomā (COST).

Savukārt, ja zinātnes projektu finansējuma saṇēmējas arī turpmāk būs zinātniskās institūcijas, ir nepieciešams mehānisms, kas ḷautu pārliecināties par to, cik efektīva ir zinātnieku atbalsta sistēma šajās institūcijās. Atbalsta sistēmas raksturojums varētu būt kritērijs, institūcijām pretendējot gan uz valsts budžeta līdzekḷu, gan ES finansējuma saņemšanu.

Projektu administratīiās vadības jautājumiem institūcijās būtu jāvelta plašāka uzmanība, lai rastu risinājumu, kā zinātniekiem mazināt slogu, ko rada ar zinātnisko darbu nesaistīti pienākumi. Koncentrēšanās uz administratīvo funkciju veikšanu var kḷūt par nopietnu šķērsli izcilības standartu sasniegšanai zinātniskajā darbā un var veicināt izdegšanu. Proti, gan ārējie $e^{72}$, gan iekšêjie ${ }^{73}$ normatīvie akti zinātnisko projektu vadītājiem, tātad zinātniekiem ar augstāko autoritāti un zinātniskajiem sasniegumiem grupā, kuri primāri ir atbildīgi par zinātniskā darba rezultātiem, nosaka vēl arī plašas administratīvās funkcijas un atbildību. Ir nepieciešamas gan grāmatvedỉbas un finanšu, gan lietvedỉbas u. c. administrativivas kompetences. Turklāt ir precedenti, kad zinātniekiem jāveic dublējošas funkcijas (piem., manuāla datu ievade nepilnīgi izstrādātu tiešsaistes sistēmas funkcionalitāšu dēl Nacionālajā zinātniskās darbības informācijas sistēmā (NZDIS), kas neḷauj dokumentus pievienot tādā formā, kā to citstarp paredz FLP projektu konkursa nolikums).

Lai pilnībā novērtētu atbalsta lìmeni, kas vismaz valsts budžeta finansētajās zinātniskajās institūcijās tiek nodrošināts zinātniekiem, būtu veicama apjomīga izpēte. 2020. gadā Latvijā reǵistrētas 64 zinātniskās institūcijas, un 22 no tām saṇem valsts budžeta finansēju$\mathrm{mu}^{74}$. Piem., Latvijas lielākajā zinātniskajā institūcijā, Latvijas Universitātē (LU), 2020. gada

71 Independent Research Fund Denmark 2021.

72 Latvijas Republikas Ministru kabinets 2017a.

73 Latvijas Universitāte 2021a.

74 Latvijas Republikas Izglītības un zinātnes ministrija $2020 \mathrm{f}$. 
budžetā centralizēts atbalsts Zinātniskās darbības atbalsta programmai tika sadalīts jau gada pirmajā ceturksnī. Tas bijis salīdzinoši niecīgs, proti, 50434 eiro. Šì summa tikusi sadalīta 43 aktivitātēm, tādēḷ atbalsta summas ir mazas, turklāt lielākā finansējuma daḷa palikusi LU centrālajā administrācijā - vairāk nekā 19000 eiro tika piešḳirti LU Zinātnes departamentam $^{75}$. Rezumējot - lielākas institūcijas pašas par sevi negarantē labvēlīgākus zinātniskā darba apstākḷus. Šis aspekts būtu jāṇem vērā, īstenojot zinātnisko institūciju fragmentācijas mazināšanu (ko citstarp paredz izstrādes stadijā esošās Zinātnes, tehnologíju attīstības un inovācijas pamatnostādnes 2021.-2027. $\operatorname{gadam}^{76}$ ). N̦emot vērā to, ka zinātnes pārvaldības resursu konsolidēšana ${ }^{77}$ politikas plānotāju izpratnē tiek vienādota ar kapacitātes stiprināšanu, ir jāgūst pārliecība, ka lielākas institūcijas patiešām uzrāda augstāku veiktspēju arī šajā - zinātniskā darba atbalsta - dimensijā.

2013. gadā veiktajā zinātnisko institūciju izvērtējumā starp zinātniskajām institūcijām un to struktūrvienību administrācijām veltītiem atzinīgiem komentāriem atsevišķos gadījumos norādīts arī uz nepietiekamu dokumentācijas caurredzamību un administratīvās vadības vīzijas un radošuma trūkumu, kā arī negatīvi izcelta konservatīva un defensīva administrācijas attieksme ${ }^{78}$. Kopumā zinātnes kopienā būtu jākultivē iesaistīto pušu konsenss un ideja par to, ka mūsdienīga zinātnes darba organizācija prasa augsta līmeņa administratīvo veiktspēju, dinamiku, kā arī sadarbỉbas un komunikācijas prasmi.

Administratīvais slogs zinātniekiem ievērojami saruktu, ja palielinātos valsts budžeta finansēto pētniecības projektu ipatsvars. Neraugoties uz administratīvām nepilnībām projektu pārvaldīšanā, ES struktūrfondu projekti pēc uzbūves ir sarežğîti un to administrēšana ir īpaši birokrātiska ${ }^{79}$.

\footnotetext{
75 Latvijas Universitāte 2021b.

${ }^{76}$ Latvijas Republikas Izglìtības un zinātnes ministrija 2020b.

77 Latvijas Republikas Ministru kabinets 2019b.

78 Segal et al. 2013.

79 Arnold et al. 2014.
}

ANO lietpratēji rekomendē valstīm pēc Covid-19 krīzes pārlūkot un pastiprināt pētniecībai un attīstībai paredzētos finanšu mehānismus. 2008. gada finanšu krīzē gūtā pieredze liecina, ka tās valstis, kuru inovāciju sistēmas bija salīdzinoši vājākas, no krīzes cieta vairāk un finansējuma samazināšana pētniecībai un attīstîbai bremzēja šādu valstu attīstību. Tika kavēti sabiedrības noturības attīstîšanas procesi, kā arī uz zināšanām balstītas ekonomikas veidošana. Arī Latvijā globālās finanšu krīzes ietekme uz zinātnes nozari bija postoša un ar ilglaicīgām sekām. ${ }^{80}$ 2009. gadā finansējuma apmērs zinātnei bija vairs tikai $60 \%$ no iepriekšējā gada līmeņa, pirmskrīzes rādītājus sasniedzot tikai 2014. gadā. Ieguldījumu apmērs zinātnē, cik vien iespējams, būtu jāsaglabā pat smagos fiskālajos apstākḷ̆os ${ }^{81}$, kādi var būt sagaidāmi pēc Covid-19 krīzes.

\section{Secinājumi}

Latvijas zinātnieki sasniedz pasaules līmeņa rezultātus zinātnē, neraugoties uz daudzreiz mazāku saņemto finansējumu nekā vidēji ES, nepietiekamu atbalstu administratīvo funkciju veikšanai ievērojama administratīvā sloga apstākḷos un neprognozējamu karjeras vidi. Ilgtspèjīgai zinātnes politikai, tostarp zinātniskā darba vērtēšanas sistēmai, būtu jārespektē fakts, ka izcilības standartu sasniegšanai zinātnē vajadzīgi labvēlīgi apstākḷi un nosacījumi, ko valsts lìdz šim nav nodrošinājusi optimālā apmērā.

Zinātnieka karjeras pievilcīgumu Latvijā mazina tādi faktori kā publiskās valsts varas institūciju un zinātni administrējošo institūciju nekonsekvence lēmumu pieņemšanā un pieņemto lēmumu izpildē (tostarp par finansējumu zinātnei), terminēts darbs un neprognozējama darba samaksa, ko bieži vien iespējams saņemt, piesaistot galvenokārt konkursu kārtîbā iegūtu finansējumu (tātad tas ir pieejams nelielai daļai zinātnieku), birokrātiskas zinātniskā darba pārvaldības tradīcijas, kā arī vāja sadarbība starp zinātni administrējošām institūcijām un zinātnieku kopienu.

\footnotetext{
80 Kloviňš 2021.

81 United Nations Conference on Trade and Development 2020.
} 
Īstenotie kampaņveidīgie atbalsta pasākumi doktorantiem un jaunajiem zinātniekiem var raisit nepamatotas gaidas par karjeras perspektīvām. Šādi pasākumi, kas īstenoti, lai panāktu pozitīvu dinamiku zinātniskā personāla ataudzē, būtu jālīdzsvaro ar pasākumiem, kas palielina nodarbinātības un atlīdzības garantijas zinātniekiem vēlīnākos karjeras posmos (t. i., pastāvīgas nodarbinātības modelii, bāzes finansējuma un zinātnisko projektu finansējuma būtisks palielinājums u. c.). Būtu jāvairās no politikas un finansēšanas risinājumiem, kas veicina noteiktu rādìtāju uzlabošanos īstermiṇā, taču neiekḷaujas plašākā sistēmiskā ilgtermiņa risinājumu programmā.

Zinātnieki zinātniskā darba organizācijā Latvijā daudzējādā ziṇā atrodas hierarhiskās padotības zemākajā posmā. Projektu zinātnisko vadītāju hierarhiskā padotība dažādām institūcijām, to struktūrvienībām un amatpersonām veido smagnējas administratīvās konstrukcijas, tāpēc izveidojies neskaidrs kompetenču sadalījums, kas kavē zinātnieku tiešo pienākumu veikšanu, kā arī nereti ietver akadēmiskās brīvības ierobežojumu riskus. Tādēl būtu veicināma zinātnisko grupu vadītāju autonomija un mazināma to darbības pakārtotība ārējiem faktoriem.

Situācijā, kad zinātnei ilgstoši netiek atvēlēts optimāls finansējums, kas turklāt atbilstu normativajos aktos noteiktajam apmēram, sevišķi būtiski ir raudzities, lai ierobežotie pieejamie līdzekḷi tiktu ieguldīti tieši zinātnisko ideju ìstenošanā, iespējami maz lìdzekļu tērējot administratīvos starpniekposmos, caur kuriem tiek novadìts finansējums, kā arī funkcijām, kas var dublēties. Jautājumi par zinātnieku nodarbinātības nosacijumiem un atlīdzību nav atliekami, lai nacionālā zinātne bùtu ilgtspèjīga.

Raksts tapis Fundamentālo un lietišķo pètījumu programmas projektā Vēstures politizācija: postfaktuālās pieejas Latvijas un Krievijas attiecībām XX gadsimtā, instrumentalizācija, izaicinājumi demokrātijai, mācības un pretlìdzekḷi (lzp-2018/1-0322).

\section{VĒRES}

Ambote, S. (2015) Jauno zinātnieku strupcelšs: nestabils darbs un niecīga alga. LSM.lv (07.07.2015.). Pieejams: https://www.lsm.lv/raksts/zinas/zinu-analize/jauno-zinatnieku-strupcels-nestabils-darbs-un-nieciga-alga. a136588/ (21.02.2021.).

Arnold, E.; Knee, P.; Angelis, J.; Giarraca, F.; Grinice, E.; Jávorka, Z.; Reid, A. (2014) Latvia: Innovation System Review and Research Assessment Exercise: Final Report. Brighton : Technopolis Group. Pieejams: https://www.researchgate.net/publication/312593088_Latvia_Innovation_System_Review_and_Research_ Assessment_Exercise (17.12.2020.).

Balcare, K. (2019) Universitātē pilnveido pētniecības projektu atbalsta programmu (03.04.2019.). Pieejams: https://www.ozolzile.lu.lv/par-mums/zinas/zina/t/49243/ (08.02.2021.).

Bažbauers, G.; Kurzemniece, I. (2014) Zinātnes nozaru izvērtējums specializāciju noteikšanai pētniecībā. Akadēmiskā Dzīve, 2013/2014, 50. Pieejams: https://www.lu.lv/en/par-mums/lu-mediji/zurnali/ akademiska-dzive/arhivs/50/ (15.12.2020.).

Bela, B.; Bērziņš, K.; Krebs, V.; Mieriņa, I.; Vingre, A. (2018) Latvijas zinātnieku diaspora: sadarbības tīkli un iespējas. Pētījuma rezultāti. Rīga : LU SZF SPPI Diasporas un migrācijas pētījumu centrs. Pieejams: https://www.izm.gov.lv/lv/media/4687/download (22.12.2020.).

Billiet, J.; Bocken, H.; Bruynseraede, Y.; Clarysse, W.; De Dijn, H.; De Mey, M.; De Schutter, G.; Schamp, N.; Simons, L.; Storme, M.; Van Houtte, P.; Willems, D.; Witte, E. (2004) Bibliometrie in de Humane Wetenschappen. Standpunten, 3. Brussel : Koninklijke Vlaamse Academie van België. Pieejams: https:// www.kvab.be/sites/default/rest/blobs/481/mw_bibliometrie.pdf (28.01.2021.).

Bonaccorsi, A. (2018) The Evaluation of Research in Social Sciences and Humanities. Springer International Publishing.

Centrālā Statistikas pārvalde (2020) Zinātniski pētnieciskajā darbā strādājošo skaits. Pieejams: $h t t p s: / / w w w$. csb.gov.lv/lv/statistika/statistikas-temas/zinatne-ikt/zinatne/tabulas (15.01.2021.).

Deklarācija par Artura Krišjāṇa Kariṇa vadītā Ministru kabineta iecerēto darbību (2019) Pieejams: https:// www.mk.gov.lv/sites/mk/files/media_file/kk-valdibas-deklaracija_red-gala-1.pdf (15.02.2021.).

DORA (2012) San Francisco Declaration on Research Assessment. Pieejams: https://sfdora.org/read/ (23.02.2021.). 
Eiropas Komisija (2020) İpašais atbalsts - cilvēkkapitāla attīstība pētniecībai un inovācijām Latvijā. Luksemburga: Eiropas Savienības Publikāciju birojs. Pieejams: https://rio.jrc.ec.europa.eu/sites/default/ files/report/PSF\%20LATVIA_Policy_messages_LV.pdf (29.01.2021.).

European Commission (2019) Country Report Latvia 2019 (27.02.2019). Brussels. Pieejams: https://ec.europa. eu/info/sites/default/files/file_import/2019-european-semester-country-report-latvia_en.pdf (29.01.2021.).

European Commission (2020a) Country Report Latvia 2020 (26.02.2020). Brussels. Pieejams: https://eur-lex. europa.eu/legal-content/EN/TXT/?qid=1584543810241 \&uri=CELEX\%3A52020SC0513 (29.01.2021.).

European Commission (2020b) A European strategy for smart, sustainable and inclusive growth. Pieejams: https://ec.europa.eu/eu2020/pdf/COMPLET\%20EN\%20BARROSO\%20\%20\%20007\%20-\%20Europe\%20 2020\%20-\%20EN\%20version.pdf (16.01.2021.).

Eurostat (2021) GERD by sector of performance (11.03.2021). Pieejams: https://ec.europa.eu/eurostat/ databrowser/view/RD_E_GERDTOT_custom_274016/bookmark/table?lang=en\&bookmarkId=0 229b449-5db5-4f0a-9412-b7a525fff3da (18.12.2020.).

Griniece, E.; Nausedaite, R. (2017) Latvian Research Funding System: Background Report. Luxembourg: Publications Office of the European Union. Pieejams: https://rio.jrc.ec.europa.eu/sites/default/files/report/ KI-AX-17-007-EN-N\%20Latvia.pdf (27.12.2020.).

Independent Research Fund Denmark (2021) Call for proposals Autumn 2020 and Spring 2021. Pieejams: https://dff.dk/en/grants/dff_e2020_f2021_uk.pdf (13.01.2021.).

Jahn, N. (2017) Conventional and innovative methods for research assessment. Pieejams: https://www. biblioteka.lu.lv/par-mums/zinas/zina/t/23074/ (18.01.2021.).

Karnīte, R. (2019) Ekspertu konsilija Zinātnes politika - humanitāro un sociālo zinātñu loma valsts un sabiedrības attīstībā ziņojums un slēdziens. Latvijas Zinātņu Akadēmijas Vēstis, 73, 2, 80-106. Pieejams: http://archive.lza.lv/LZA_VestisA/73_2/7_EKSPERTU\%20KONSILIJA.pdf (23.11.2020.).

Kloviņš, J. (2021) Zinātne un zinātnes politika Latvijā. Nacionālā enciklopēdija (26.04.2021.). Pieejams: https:// enciklopedija.lv/skirklis/5430-zin\%C4\%81tne-un-zin\%C4\%81tnes-politika-Latvij\%C4\%81 (16.03.2021.).

Krumberga, K. (2018) Viedās specializācijas stratēǵija - ceḷvedis uz inovācijām. Enerǵija un Pasaule, 2018/5, 54-57. Pieejams: http://www.energijaunpasaule.lv/wp-content/uploads/2018/10/celvedis_uz_inovacijam. $p d f(16.01 .2021$.$) .$

Latvijas nacionālā reformu programma Eiropa 2020 stratēǵijas īstenošanai. Progresa ziṇojums (2017). Pieejams: https://ec.europa.eu/info/sites/default/files/2017-european-semester-national-reform-programme-latvia-lv. $p d f$ (19.03.2021.).

Latvijas Republikas Ekonomikas ministrija (2018) Noteikumu projekts Saraksts ar specialitātēm (profesijām), kurās prognozē būtisku darbaspēka trūkumu un kurās darbā Latvijas Republikā var tikt uzaicināti ārzemnieki (20.02.2018). Pieejams: http://tap.mk.gov.lv/lv/mk/tap/?pid=40425903 (29.12.2020.).

Latvijas Republikas Ekonomikas ministrija (2020) Progresa ziņojums par Latvijas nacionālās reformu programmas Eiropa 2020 stratēgijas kontekstā ìstenošanu. Projekts (30.04.2020). Pieejams: http://tap. mk.gov.lv/lv/mk/tap/?pid=40486710\& mode $=$ mk\&date $=2020-04-30$ (11.02.2021.).

Latvijas Republikas Izglìīibas un zinātnes ministrija (2015) Pēcdoktorantūras pētniecības atbalsts: Eiropas Savienības struktūrfondi 2014.-2020. gadam: Sākotnējais novērtējums. Rīga. Pieejams: https://www. sportaregistrs.lv/images/strukturfondi/IZM_SN_SAM111_Post-doc_160315.pdf (16.11.2020.).

Latvijas Republikas Izglìīibas un zinātnes ministrija (2016) Noteikumu projekts Darbïbas programmas Izaugsme un nodarbinātība 1.1.1. specifiskā atbalsta mērķa Palielināt Latvijas zinātnisko institūciju pētniecisko un inovatīvo kapacitāti un spēju piesaistīt ārējo finansējumu, ieguldot cilvēkresursos un infrastruktūrā 1.1.1.4. pasākuma $\mathrm{P} \& \mathrm{~A}$ infrastruktūras attīstīšana Viedās specializācijas jomās un zinātnisko institūciju institucionālās kapacitātes stiprināšana ìstenošanas noteikumi (16.08.2016). Pieejams: http://tap.mk.gov.

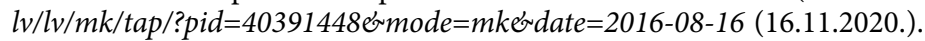

Latvijas Republikas Izglītības un zinātnes ministrija (2020a) Informatīvais ziṇojums Viedās specializācijas stratēgijas monitorings: Otrais ziņojums. Projekts (10.03.2020.). Pieejams: http://tap.mk.gov.lv/lv/mk/ tap/?dateFrom $=2020-01-17 \&$ dateTo=2021-01-16ぬtext $=$ vied $\% C 4 \% 81$ s + specializ\%C4\%81cijas + strat $\%$ C4

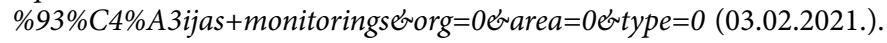

Latvijas Republikas Izglītibas un zinātnes ministrija (2020b) Akadēmiskās karjeras ietvars Latvijai: ieceru ziņojums. Projekts (22.09.2020.). Pieejams: https://www.izm.gov.lv/sites/izm/files/data_content/akademiskas-karjeras-ietvars-latvijai-ieceru-zinojums_latviski.pdf (17.01.2021.). 
Latvijas Republikas Izglìitibas un zinātnes ministrija (2020c) Likumprojekts Grozījumi Augstskolu likumā (12.05.2020.). Pieejams: http://tap.mk.gov.lv/lv/mk/tap/?pid=40484842ঊmode=mkむdate=2020-05-12 (18.02.2021.).

Latvijas Republikas Izglìtības un zinātnes ministrija (2020d) Valdība atbalsta izcilības grantu pieškiršanu Latvijas zinātniekiem (11.08.2020.). Pieejams: https://www.izm.gov.lv/lv/jaunums/valdiba-atbalstaizcilibas-grantu-pieskirsanu-latvijas-zinatniekiem (02.06.2021.).

Latvijas Republikas Izglitīibas un zinātnes ministrija (2020e) Reform of the Academic Career Model in Latvia: Analysis of Legislation I (09.2020.). Pieejams: https://www.izm.gov.lv/sites/izm/files/data_content/ aki_reforma_latvija-normativa_regulejuma_analize_i_angliski.pdf (02.02.2021.).

Latvijas Republikas Izglīīibas un zinātnes ministrija (2020f) Zinātniskās institūcijas (07.09.2020.). Pieejams: https://www.izm.gov.lv/lv/zinatniskas-institucijas (16.12.2020.).

Latvijas Republikas Izglītỉbas un zinātnes ministrija (2020g) 2020. gada zinātnes bāzes finansējums (19.11.2020.). Pieejams: https://www.izm.gov.lv/lv/2020-gada-zinatnes-bazes-finansejums (03.02.2021.).

Latvijas Republikas Izglīīibas un zinātnes ministrija (2020h) 107 Latvijas zinātnieki īstenos sabiedrībai būtiskus pētījumus visas zinātnes nozarēs (12.11.2020.). Pieejams: https://lvportals.lv/dienaskartiba/321883-107latvijas-zinatnieki-istenos-sabiedribai-butiskus-petijumus-visas-zinatnes-nozares-2020 (12.06.2021.).

Latvijas Republikas Izglìīibas un zinātnes ministrija (2020i) IZM veidotās valsts pētijumu programmas (09.12.2020.). Pieejams: https://www.izm.gov.lv/lv/izm-veidotas-valsts-petijumu-programmas (16.02.2021.).

Latvijas Republikas Izglìīibas un zinātnes ministrija (2021a) Citu ministriju valsts pētijumu programmas (14.01.2021.). Pieejams: https://www.izm.gov.lv/lv/citu-ministriju-valsts-petijumu-programmas (25.01.2021.).

Latvijas Republikas Izglìīibas un zinātnes ministrija (2021b) 2021. gada zinātnes bāzes finansējums (18.01.2021.). Pieejams: https://www.izm.gov.lv/lv/2021-gada-zinatnes-bazes-finansejums (17.02.2021.).

Latvijas Republikas Ministru kabinets (2009) Par prioritārajiem zinātnes virzieniem fundamentālo un lietišḳo pētījumu finansēšanai 2010.-2013. gadā. Rīkojums Nr. 594 (31.08.2009.). Pieejams: https:/likumi.lv/ ta/id/196878-par-prioritarajiem-zinatnes-virzieniem-fundamentalo-un-lietisko-petijumu-finansesanai20102013gada (21.12.2020.).

Latvijas Republikas Ministru kabinets (2013a) Kārtība, kādā aprēḳina un pieškị bāzes finansējumu zinātniskajām institūcijām. Noteikumi Nr. 1316 (12.11.2013.). Pieejams: https://likumi.lv/ta/id/262508kartiba-kada-aprekina-un-pieskir-bazes-finansejumu-zinatniskajam-institucijam (26.11.2020.).

Latvijas Republikas Ministru kabinets (2013b) Zinātnes, tehnolog̣ijas attīstības un inovācijas pamatnostādnes 2014.-2020. gadam (informatīvā daļa). Rīkojums Nr. 685 (28.12.2013.). Pieejams: https://www.izm.gov. lv/sites/izm/files/ztaip_2014-20201_0.pdf(17.02.2021.).

Latvijas Republikas Ministru kabinets (2016a) Darbïbas programmas Izaugsme un nodarbinātība 1.1.1. specifiskā atbalsta mērķa Palielināt Latvijas zinātnisko institūciju pētniecisko un inovatīvo kapacitāti un spēju piesaistīt ārējo finansējumu, ieguldot cilvēkresursos un infrastruktūrā 1.1.1.1. pasākuma Praktiskas ievirzes pētījumi îstenošanas noteikumi. Noteikumi Nr. 34 (12.01.2016.). Pieejams: https://likumi.lv/ta/ id/279475-darbibas-programmas-izaugsme-un-nodarbinatiba-1-1-1-specifiska-atbalsta-merka-palielinatlatvijas-zinatnisko-instituciju (18.11.2020.).

Latvijas Republikas Ministru kabinets (2016b) Darbïbas programmas Izaugsme un nodarbinātība 1.1.1. specifiskā atbalsta mērḳa Palielināt Latvijas zinātnisko institūciju pētniecisko un inovatīvo kapacitāti un spēju piesaistìt ärējo finansējumu, ieguldot cilvēkresursos un infrastruktūrā 1.1.1.2. pasākuma Pēcdoktorantūras pētniecības atbalsts isstenošanas noteikumi. Noteikumi Nr. 50 (19.01.2016.). Pieejams: https://likumi.lv/ta/ id/279803-darbibas-programmas-izaugsme-un-nodarbinatiba-1-1-1-specifiska-atbalsta-merka-palielinatlatvijas-zinatnisko-instituciju (18.11.2020.).

Latvijas Republikas Ministru kabinets (2017a) Fundamentālo un lietišḳo pētijumu projektu izvērtēšanas un finansējuma administrēšanas kārtība. Noteikumi Nr. 725 (12.12.2017.). Pieejams: https:/likumi.lv/ta/ id/295784-fundamentalo-un-lietisko-petijumu-projektu-izvertesanas-un-finansejuma-administresanaskartiba (18.11.2020.).

Latvijas Republikas Ministru kabinets (2017b) Par prioritārajiem virzieniem zinātnē 2018.-2021. gadā. Rikojums Nr. 746 (13.12.2017.). Pieejams: https://likumi.lv/ta/id/295821-par-prioritarajiem-virzieniemzinatne-2018-2021-gada (16.12.2020.).

Latvijas Republikas Ministru kabinets (2018) Valsts pētijumu programmu projektu īstenošanas kārtība. Noteikumi Nr. 560 (04.09.2018.). Pieejams: https://likumi.lv/ta/id/301438-valsts-petijumu-programmuprojektu-istenosanas-kartiba (27.12.2020.). 
Latvijas Republikas Ministru kabinets (2019a) Latvijas Zinātnes padomes ekspertu tiesỉbu pieškiršanas un ekspertu komisiju izveides kārtiba. Noteikumi Nr. 320 (09.07.2019.). Pieejams: https://likumi.lv/ta/ id/308118-latvijas-zinatnes-padomes-ekspertu-tiesibu-pieskirsanas-un-ekspertu-komisiju-izveides-kartiba (02.06.2021.).

Latvijas Republikas Ministru kabinets (2019b) Par konceptuālo ziņojumu Par Latvijas zinātnes politikas ieviešanas sistēmas institucionālo konsolidāciju. Rīkojums Nr. 495 (14.10.2019.). Pieejams: https:// likumi.lv/ta/id/309955-par-konceptualo-zinojumu-par-latvijas-zinatnes-politikas-ieviesanas-sistemasinstitucionalo-konsolidaciju (05.01.2021.).

Latvijas Republikas Ministru kabinets (2020) Par konceptuālo ziṇojumu Par jauna doktorantūras modeḷa ieviešanu Latvijā. Rỉkojums Nr. 345 (25.06.2020.). Pieejams: https://likumi.lv/ta/id/315685-parkonceptualo-zinojumu-par-jauna-doktoranturas-modela-ieviesanu-latvija (05.01.2021.).

Latvijas Republikas Ministru kabinets (2021) Par Zinātnes, tehnolog̣ijas attīstības un inovācijas pamatnostādnēm 2021.-2027. gadam. Rỉkojums Nr. 246 (14.04.2021.). Pieejams: https://likumi.lv/ta/id/322468-parzinatnes-tehnologijas-attistibas-un-inovacijas-pamatnostadnem-20212027-gadam (16.05.2021.).

Latvijas Republikas Saeima (2005) Zinātniskās darbības likums. Pieejams: https://likumi.lv/ta/id/107337zinatniskas-darbibas-likums (04.11.2021.).

Latvijas Republikas Saeima (2010) Latvijas ilgtspējīgas attīstības stratēgija līdz 2030. gadam. Pieejams: https:// www.pkc.gov.lv/sites/default/files/inline-files/Latvija_2030_6.pdf (17.11.2020.).

Latvijas Republikas Saeima (2018) Grozījumi Zinātniskās darbības likumā (21.06.2018.). Pieejams: https:// likumi.lv/ta/id/299945-grozijumi-zinatniskas-darbibas-likuma (19.11.2020.).

Latvijas Republikas Valsts kontrole (2017) Izvērtējums par ḷoti mazo un mazo valsts tiešās pārvaldes iestāžu darbību. Rīga.

Latvijas Universitāte (2017) Par Kārtības stundas tarifa likmes noteikšanu apstiprināšanu. Rīkojums Nr. 1/98 (20.03.2017.).

Latvijas Universitāte (2018) Izsludināts 2018. gada otrais fundamentālo un lietišķo pētijjumu projektu konkurss (18.07.2018.). Pieejams: https://www.cfi.lu.lv/par-mums/zinas/zina/t/43698/ (25.11.2020.).

Latvijas Universitāte (2021a) Projektu īstenošanas noteikumi. Pieejams: https://www.lu.lv/zinatne/atbalstspetniecibai-lu/projektu-istenosanas-noteikumi/ (04.03.2021.).

Latvijas Universitāte (2021b) Zinātniskās darbības atbalsta programma. Pieejams: https://www.lu.lv/zinatne/ atbalsts-petniecibai-lu/zinatniskas-darbibas-atbalsta-programma/ (04.02.2021.).

Latvijas Valsts prezidenta kanceleja (2009) Stratēǵiskās analīzes komisijas skatījums uz sociālo, pārvaldības, izglìtības un zinātnes jomu Latvijā: neatliekamie ìstermiṇa pasākumi un vidēja termiña mērḳi un ieteikumi rīcībai (02.04.2009.). Pieejams: $h t t p s: / / w w w . p r e s i d e n t . l v / l v / j a u n u m i / z i n a s / s t r a t e g i s k a s-a n a l i z e s-$ komisijas-skatijums-uz-socialo-parvaldibas-izglitibas-un-zinatnes-jomu-latvija-neatliekamie-isterminapasakumi-un-videja-termina-merki-un-ieteikumi-ricibai-13495\#gsc.tab=0 (13.11.2020.).

Latvijas Valsts prezidenta kanceleja (2020) Valsts prezidents: zinātnes finansējuma trūkuma dēl daudzas Latvijas valstij nozīmīgas nozares paliek neizpētītas (26.10.2020.). Pieejams: https://www.president.lv/ lv/jaunumi/zinas/valsts-prezidents-zinatnes-finansejuma-trukuma-del-daudzas-latvijas-valstij-nozimigasnozares-paliek-neizpetitas-26459\#gsc.tab $=0$ (12.03.2021.).

Latvijas Zinātnes padome (2018a) 2018. gada fundamentālo un lietiškso pētijumu projektu konkursa nolikums (02.02.2018.). Piejams: https://lzp.gov.lv/wp-content/uploads/2020/10/FLPP_nolikums_01.02.2018.pdf (27.12.2020.).

Latvijas Zinātnes padome (2018b) 2018. gada pirmā fundamentālo un lietišḳo pētijumu projektu konkursa izvērtēšanas pārskats. Rīga. Pieejams: https://lzp.gov.lv/wp-content/uploads/2020/10/FLPP_2018_1_ PARSKATS-1.pdf (12.11.2020.).

Latvijas Zinātnes padome (2019) 2019. gada fundamentālo un lietišķo pētījumu projektu konkursa nolikums (22.05.2019.). Pieejams: https://lzp.gov.lv/wp-content/uploads/2020/10/flpp_2019_nolikums.pdf (27.12.2020.).

Latvijas Zinātnes padome (2020) 2020. gada fundamentālo un lietišķo pētījumu projektu konkursa izvērtēšanas pārskats. Rīga. Pieejams: https://lzp.gov.lv/wp-content/uploads/2020/12/FLPP_2020_konkursa_ izvertesanas_parskats.pdf (27.12.2020.).

Latvijas Zinātnes padome (2021) Par fundamentālo un lietišķo pētijumu projektu konkursa norisi 2021. gadā (20.01.2021). Pieejams: https://lzp.gov.lv/2021/01/20/aktuali-par-fundamentalo-un-lietisko-petijumuprojektu-konkursa-norisi-2021-gada/ (03.03.2021.). 
Marx, W.; Bornmann, L. (2013) Journal Impact Factor: "the poor man's citation analysis" and alternative approaches. European Science Editing, 39, 3, 62-63. Pieejams: https://www.researchgate.net/profile/LutzBornmann/publication/268077675_Journal_impact_factor_the_poor_man\%27s_citation_analysis_and_ alternative_approaches/links/5c54475092851c22a3a101c5/Journal-impact-factor-the-poor-mans-citationanalysis-and-alternative-approaches.pdf (18.01.2021.).

McIntyre, L. (2018) Post-Truth. Cambridge : The MIT Press.

Metris (2011) Country Report: Social Sciences and Humanities in Latvia: 2011. European Commission.

Ochsner, M.; Hug, S. E.; Daniel, H.-D. (2012) Indicators for Research Quality for Evaluation of Humanities Research: Opportunities and Limitations. Bibliometrie - Praxis und Forschung, 1, 4-1-4-17. Pieejams: https://d-nb.info/1029494584/34 (26.01.2021.).

OECD Economic Surveys: Latvia 2019. Paris: OECD Publishing. Pieejams: https://www.oecd-ilibrary.org/ economics/oecd-economic-surveys-latvia_25222988 (18.12.2020.).

Orupe, A. (2019) Zinātnieku algas joprojām zemas un nekonkurētspējīgas. NRA.lv (14.06.2020.). Pieejams: https://nra.lv/latvija/izglitiba-karjera/283773-zinatnieku-algas-joprojam-zemas-un-nekonkuretspejigas. htm (16.12.2020.).

Par nacionālās zinātnes stabilu un ilgtspējīgu attīstību: Latvijas zinātnieku atklātā vēstule. Ir.lv (18.01.2021.). Pieejams: https://ir.lv/2013/01/16/par-nacionalas-zinatnes-stabilu-un-ilgtspejigu-attistibu/ (03.06.2021.).

Pārresoru koordinācijas centrs (2020) Latvijas nacionālais attīstības plāns 2021.-2027. gadam. Rīga. Pieejams: https://www.pkc.gov.lv/sites/default/files/inline-files/NAP2027_apstiprin\%C4\%81ts\%20Saeim\%C4\%81_1. $p d f$ (19.01.2021.).

Pellens, M.; Peters, B.; Rammer, C.; Licht, G. (2016) Public investment in R\&D in reaction to economiccrises: A longitudinal study for OECD countries. SPINTAN Working Paper Series, 16. Valencia: Instituto Valenciano de Investigaciones Económicas. Pieejams: $h t t p: / / w w w . s p i n t a n . n e t / w p$-content/uploads/public/ WP_16_Pellens_Peters_Rammer_Licht.pdf (25.11.2020.).

Rozenberga, G. (2017) Pieejams LU Bibliotēkas semināra Vispārpieñemtās un inovatìvās pētniecības sasniegumu novērtēšanas metodes videoieraksts (28.11.2017.). Pieejams: https://www.biblioteka.lu.lv/par-mums/zinas/ zina/t/23074/ (18.12.2020.).

Segal, N.; Koleva, D.; Sausverde, E.; Larsen, S. E.; Blockmans, W. (2013) Latvia: Research Assessment Exercise: Panel Report: Humanities. Brighton: Technopolis Group. Pieejams: https://www.izm.gov.lv/sites/izm/ files/data_content/zisi_061.pdf (01.02.2021.).

Shah, H. (2020) Global problems need social science. Springer Nature (24.01.2020.). Pieejams: https://www. nature.com/articles/d41586-020-00064-x (17.01.2021.).

Spaapen, J.; Dijstelbloem, H.; Wamelink, F. (2007) Evaluating Research in Context: A method for comprehensive assessment. Hague : Consultative Committee of Sector Councils for Research and Development (COS). Pieejams: https://www.qs.univie.ac.at/fileadmin/user_upload/d_qualitaetssicherung/Dateidownloads/ Evaluating_Research_in_context_-_A_method_for_comprehensive_assessment.pdf (12.01.2021.).

Stradiņš, J. (1995) Zinātne Latvijā - laika svaros Baltijas pētijumu konferences atskan̄ās (01.09.1995). Latvijas Vēstnesis, 133. Pieejams: https://www.vestnesis.lv/ta/id/27509 (22.12.2020.).

The World Bank Group (2021) Researchers in R\&D (per million people). Pieejams: https://data.worldbank. org/indicator/SP.POP.SCIE.RD.P6 (03.02.2021.).

Toledo, E. G. (2018) Research assessment in Humanities and Social Sciences in review. Revista Española de Documentación Científica, 41, 3, 1-14. Pieejams: http://redc.revistas.csic.es/index.php/redc/article/ view/1012/1627 (12.01.2021.).

UNESCO Institute of Statistics (2019) New UIS Data for SDG 9.5 on Research and Development (19.06.2019). Pieejams: http://uis.unesco.org/en/news/new-uis-data-sdg-9-5-research-and-development (23.12.2020.).

United Nations Conference on Trade and Development (2020) The need to protect science, technology and innovation funding during and after the COVID-19 crisis. Policy Brief, 80. Pieejams: https://unctad.org/ system/files/official-document/presspb2020d4_en.pdf(12.01.2021.).

University of Oulu (2021) Evaluation based on scientific publishing: Citation analysis and databases containing citation information (24.03.2021.). Pieejams: https://libguides.oulu.fi/evaluatingpublications/ citationanalysis (26.03.2021.).

Valsts izglīìibas attīstības aǵentūra (2020) Taps video sižeti par pēcdoktorantūras pētniecības pieteikumu rezultātiem (30.10.2020.). 
Valtenbergs, V.; Kalniņš, V.; Grumolte-Lerhe, I.; Beizītere, I. (2019) Lobēšanas normatīvais regulējums un problemātika Latvijā un Eiropā. Rīga: Latvijas Republikas Saeima. Pieejams: https://www.saeima.lv/ petijumi/Lobesana_Latvija_un_Eiropa_2019.pdf (17.01.2021.).

Veidemane, E. (2020) Ne tikai politiskā, bet arī zināšanu vara vajadzīga. [Intervija ar Ivaru Kalviņu, Andreju Ērgli, Ojāru Spārīti un Baibu Rivžu.] Neatkarīgā Rìta Avīze, 20.02.2020.

Vrielink, J.; Lemmens, P.; Parmentier, S. (2011) Academic Freedom as a Fundamental Right. Procedia Social and Behavioral Sciences, 13, 117-141. Pieejams: https://www.sciencedirect.com/science/article/pii/ S1877042811001790 (18.01.2021.).

Zinātne Latvijā: attīstības pamatmetu raksturojums (1775-2016). Acta medico-historica Rigensia, XI: 11-52. Pieejams: https://dspace.rsu.lv/jspui/bitstream/123456789/460/1/amhr.2018.XI.11-52.pdf (14.12.2020.). 